\title{
Chapter 28 \\ Investigating the Role of Motivation \\ in Strengthening Entrepreneurial \\ Intention Among Women Entrepreneurs \\ in India
}

\author{
Sakshi Chhabra, Rajasekaran Raghunathan, \\ and Navuluru Venkata Muralidhar Rao
}

\begin{abstract}
The purpose of this paper is to explore the key factors, which motivate women to take up entrepreneurial activity and to understand its role in increasing Entrepreneurial intention towards women entrepreneurs in Indian micro, small and medium enterprises. This paper attempts to develop a scale for measuring motivational factors, entrepreneurial potential that leads to entrepreneurial intention among women entrepreneurs in India and hence testing its validation. In addition, it will help in understanding the relationship between motivation, entrepreneurial potential and intention through hypothesis testing. The paper adopts an exploratory and descriptive research design capitalizing on authentic and reliable secondary data through exhaustive studies of reputed journals/literatures, government sources. A sample of 397 respondents from all across the India has been collected from women entrepreneurs for this study in order to understand the motivational factors and its role in increasing entrepreneurial intention, using cluster and snowball sampling on self-administered questionnaire. The accumulated data were than analyzed using descriptive analysis for validity and reliability checks. Strong correlations were found between motivational factors, perceived desirability, entrepreneurial potential and intention and hence confirmed that all the measures in the instrument were well constructed. Hypothesis testing using Spearmen's correlation test (two tailed) explains the significance of relationship between the variables.
\end{abstract}

\footnotetext{
S. Chhabra $(\bowtie)$

Department of Management, Birla Institute of Technology and Science, Pilani, Pilani-Campus, Pilani 333031, RJ, India

e-mail: p2014011@pilani.bits-pilani.ac.in

R. Raghunathan

Department of Economics and Finance, Birla Institute of Technology and Science, Pilani, Hyderabad-Campus, Hyderabad 500078, TN, India

e-mail: raghu@hyderabad.bits-pilani.ac.in

N. V. M. Rao

Department of Economics and Finance, Birla Institute of Technology and Science, Pilani,

Pilani-Campus, Pilani 333031, RJ, India

e-mail: nvmrao@pilani.bits-pilani.ac.in
}

K. S. Sangwan and C. Herrmann (eds.), Enhancing Future Skills and Entrepreneurship, Sustainable Production, Life Cycle Engineering and Management, https://doi.org/10.1007/978-3-030-44248-4_28 
Keywords Women entrepreneurship - Motivation · Entrepreneurial intention

\subsection{Introduction}

The twenty-first century has witnessed a paradigm shift in the role of women from being simply a home maker to a career oriented professional. This in turn led to improvement in their economic strength as well as position in society. Having realized this present day, modern women do not want to confine themselves within the boundaries of their houses. Women entrepreneurship is an act of owning a business, which makes women economically independent. It has been found that an estimated 126 million women were starting or managing new businesses in 67 countries around the world. In addition, an estimated 98 million were running established businesses. Globally men make up 52\% of all entrepreneurial activity and remaining $48 \%$ of them constituted women entrepreneurs. The gender gap in entrepreneurial activities varies across the world. It ranges from 1.5 to $45.4 \%$ women of the adult population (Kelley 2012).

Women entrepreneurship is considered to be instrumental in women's empowerment and improvement in their quality of life. Entrepreneurial activity originates at the individual level and can always be traced back to a single person, the entrepreneur. Entrepreneurship is, hence, induced by an individual's attitudes or motives, skills and psychological endowments. The gender gap in entrepreneurship is defined as the difference between men and women in terms of numbers engaged in entrepreneurial activity, motives to start or run a business, industry choice and business performance and growth. Most entrepreneurship research on individual level analysis has focused on the entrepreneurial activities of male entrepreneurs. Few Researchers in their study has criticized earlier research findings stating that there is no significant difference in male and female entrepreneurs (Carter and Cannon 1988). Several other studies were conducted with a focus on studying the gender differences in entrepreneurship. It has been observed through the studies that women entrepreneurs are different from that of men in terms of characteristics, background, motivation, entrepreneurial skills and the problems faced by them (Hisrich and Candida 1984; Lituchy and Reavley 2015; Bird and Brush 2002).

Global Entrepreneurship and Development Institute (GEDI) conducted a study and ranked India at 70 among 77 countries. In this study, India has obtained a score of 25.3 in the Female Entrepreneurship Index and the study suggested a need for significant changes to reduce the barriers for female entrepreneurs in India. This study further identified that, women entrepreneurs in India were more opportunity driven than necessity driven (Terjesen and Lloyd 2015). BNP Paribas Global Entrepreneurialism Report has ranked India on top for the highest percentage of successful women entrepreneurs. Nearly half (49\%) of successful entrepreneurs in India are female entrepreneurs. A majority of these businesses are in the micro sector (BNP Paribas 2015). One of the major study highlighted that micro, small and medium enterprises (MSME's) have been recognized as a fundamental driver for creating, running and 
growing business and consequently the economic growth of a country and this is no different for Indian economy as well (Ascher 2012). As mentioned in International finance corporation, world Bank and small and medium enterprises report (IFC Issue Brief/Small and Medium Enterprises 2010), globally MSME's constitutes about $90 \%$ of the business enterprises. This research intends to study the various motivational factors and clarifies the fact that how these factors influence the entrepreneurial intention of women entrepreneurs. The focus is also made to understand the entrepreneurial intention among women in particular studying the motivational factors that leads to entrepreneurial potential in women entrepreneurs.

\subsection{Literature Review}

Most entrepreneurship research on individual level analysis has focused on the entrepreneurial activities of male entrepreneurs. Rapid increase in the number of women owned enterprises across different countries has attracted several researchers' interest. There are not much attempts made to conduct a nation-wide comprehensive research study in order to understand the motivation, issues and challenges of women entrepreneurs. Most of the research studies are cross sectional or longitudinal studies focusing on specific regions within India, which includes Tamilnadu, Jammu and Kashmir, Meghalaya, Andhra Pradesh, Karnataka, Uttar Pradesh and Kerala (Marichamy 2013; Mani 2011; Thomas and Lavanya 2012; Mustafa 2013; Shah and Mustafa 2014; Kurbah 2013; Nagalakshmi 2015; Tarakeswara and Tulasi 2013; Shiralashetti 2014; Dwivedi and Mishra 2013; Chandrasekar et al. 2008).

An attempt is made in this study to fill these literature gaps. Hence, the literature highlights the various motivational factors and the role of these factors in influencing entrepreneurial intention among women. The comprehensive review of literature has been divided into three sections: defining Women entrepreneurship, motivational factors and its role in increasing Entrepreneurial Intention.

\subsubsection{Defining Women Entrepreneurship}

Women entrepreneurship is a subset of entrepreneurship; it also faces the difficulty of single or commonly accepted definition for the same. Researchers have defined women entrepreneurship in several ways; Table 28.1 summarizes some of these definitions.

Definition of micro, small and medium enterprises was given under Micro, small and medium enter-prises development (MSMED) Act, 2006 is considered for this study. This act defines women entrepreneurship as "a business entity which owned and managed by a woman" (Ahl 2006). It was in 1970s that the Government of India began to promote and focus on self-employment among women. Because of these 
Table 28.1 Selected definitions of women entrepreneurship

\begin{tabular}{|c|c|}
\hline Author(s) & Definition of women entrepreneurship \\
\hline Vinze (1987) & $\begin{array}{l}\text { A woman entrepreneur is a person who is an } \\
\text { enterprising individual with an eye for } \\
\text { opportunities and an uncanny vision, commercial } \\
\text { acumen, with tremendous perseverance and above } \\
\text { all a person who is willing to take risks with the } \\
\text { unknown because of the adventurous spirit she } \\
\text { possesses }\end{array}$ \\
\hline Anwar and Rashid (2012) & $\begin{array}{l}\text { A woman entrepreneur can be defined as a } \\
\text { confident, innovative and creative woman capable } \\
\text { of achieving self-economic independence } \\
\text { individually or in collaboration, generates } \\
\text { employment opportunities for others through } \\
\text { initiating, establishing and running the enterprise } \\
\text { by keeping pace with her personal, family and } \\
\text { social life }\end{array}$ \\
\hline Sharma (2013) & $\begin{array}{l}\text { Female entrepreneurs are defined as those who } \\
\text { use their knowledge and resources to develop or } \\
\text { create new business opportunities, who are } \\
\text { actively involved in managing their businesses, } \\
\text { and own at least } 50 \% \text { of the business and have } \\
\text { been in operation for longer than a year }\end{array}$ \\
\hline $\begin{array}{l}\text { Government of the People's Republic of } \\
\text { Bangladesh (2010) }\end{array}$ & $\begin{array}{l}\text { Woman or a group of women who initiate, } \\
\text { organize and run a business enterprise. Women } \\
\text { entrepreneur is any women who organizes and } \\
\text { manages any enterprise, usually with considerable } \\
\text { initiative and risk }\end{array}$ \\
\hline Rummana (2014) & $\begin{array}{l}\text { A woman will be termed as a Woman } \\
\text { Entrepreneur if she is the 'owner or proprietor of a } \\
\text { private or proprietary enterprise' or 'is the director } \\
\text { of a private company' registered with the 'joint } \\
\text { stock' or 'shareholding enterprise' or owning at } \\
\text { least } 51 \% \text { share among the shareholders' }\end{array}$ \\
\hline Masood (2011) & $\begin{array}{l}\text { An enterprise owned and controlled by a women } \\
\text { having a minimum financial interest of } 51 \% \text { of the } \\
\text { capital and giving at least } 51 \% \text { of the employment } \\
\text { generated in the enterprise to women }\end{array}$ \\
\hline Singh and Raina (2013) & $\begin{array}{l}\text { A woman will be termed as an Entrepreneur if she } \\
\text { is the 'owner/proprietor/director of a private/ } \\
\text { proprietary enterprise/private company' registered } \\
\text { with the 'joint stock' or 'shareholding enterprise', } \\
\text { owning at least } 51 \% \text { annual turnover and share } \\
\text { among the shareholders' and generates } \\
\text { employment opportunities for others by } \\
\text { administering the enterprise }\end{array}$ \\
\hline
\end{tabular}


initiatives, in late ninety's the concept of women entrepreneurship gained prominence. Women owned enterprises account for $25 \%$ of them. American Express OPEN report on 'State of women owned business' ranks India at 16th in terms of revenue generation by women owned enterprises. In 2009, a study carried out by Centre for women's business research indicates women entrepreneurs in India were growing twice as fast as the other business (Mallya 2012). After an extensive analysis of these studies, the following key themes emerged background, profile, characteristics, motivation and entrepreneurial Intention.

\subsubsection{Women Entrepreneurship and Motivation}

Entrepreneurial Motivation is the drive of an entrepreneur to maintain an entrepreneurial spirit in all their actions. It is an inner state, dynamic force that causes a person to act towards the attainment of goals. To accomplish entrepreneurial goals, the entrepreneur must have a drive, which activates him/her to persistently exert a certain level of effort (Mallya 2012). It includes two types of factors i.e. (Cavada et al. 2017) Push and Pull factors. Necessity Driven Factors (Push Factors) are those that forces a woman to become an entrepreneur. It includes unemployment, dissatisfaction from the job, career development and family conditions. Opportunity Driven Factors (Pull factors) are those factors that act as an opportunity and pulls a woman to choose entrepreneurial activity as a career. It include desire to generate income, provide employment to others, choose profession as a challenge, desire for self and social recognition, desire to be independent, utilization of own experience and education, keeping oneself busy, family support and encouragement, autonomy, market opportunity, knowledge and skills.

\subsubsection{Entrepreneurial Intention}

Entrepreneurial intention is defined as a state of mind that ultimately leads an individual towards forming a new business concept and making a career in entrepreneurship. Literature review revealed thirteen intention based theories. Extended Social Cognitive Career Theory and Entrepreneurial Potential Model are studied most predominantly. These two models holistically cover the major constructs mentioned in other leading entrepreneurial intention theories. This study addresses the above gaps by developing a conceptual model, which adapts Extended Social Cognitive Career Theory and Entrepreneurial Potential Model, followed by pan India data collection (Krueger and Carsrud 1995; Lent et al. 1994; Lent et al. 2000; Irengun and Arikboga 2015; Nga and Shamuganathan 2010). 


\subsection{Proposed Framework}

As envisaged in the literature review, we have observed crucial gaps. To overcome those gaps, a conceptual model has been developed which aims to serve the objective of the research study i.e. promoting women entrepreneurship in Indian MSME's. The model has used various constructs in order to understand the role of Motivation in entrepreneurial activity. The conceptual model that we have used for PAN India study is presented as follows (see Fig. 28.1).

In the proposed framework, motivational factors lead to perceived desirability, which is defined as "the degree to which starting a new venture is perceived as a desirable career option". Perceived desirability leads to entrepreneurial potential. Potential Entrepreneurs are defined as the individuals who are desirable and feasible to become an entrepreneur but are not willing to act on it. Individuals with high entrepreneurial potential are found to have high intention towards entrepreneurship. As mentioned by Krueger and Carsrud (1995) in their study entrepreneurial potential is measured through entrepreneurial mindset. Entrepreneurial mindset further can be measured from the i.e. optimism, cognitive flexibility, entrepreneurial intensity and entrepreneurial potential, action control scale. Finally, entrepreneurial potential leads to entrepreneurial intention (Krueger 2015).

\subsection{Methodology}

In-depth study of literature on women entrepreneurs has provided insight on motivational factors that contribute to entrepreneurial activities. To understand the entrepreneurial intention among women entrepreneurs in India, a nation-wide study has been done using a survey method. An instrument has been designed and administered among women entrepreneurs using cluster and snowball sampling. The study adopts exploratory and descriptive research design capitalizing on primary and secondary data. This study seeks to clarify the construct of entrepreneurial intention and then reports the validation of Entrepreneurial Intention instrument. To understand the relationship between the variables, hypothesis testing has been done using Pearson Correlation. Spearmen's Correlation is used to understand the strength of relationship between motivational factors, perceived desirability, entrepreneurial potential and intention.

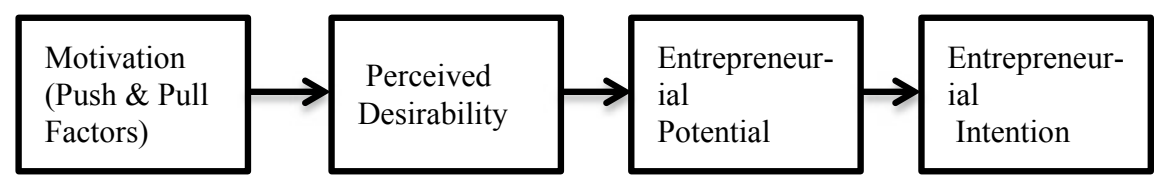

Fig. 28.1 Conceptual model for the study (Lent et al. 1994; Nga and Shamuganathan 2010) 


\subsection{Analysis}

\subsubsection{Descriptive Analysis}

Descriptive statistics is required to explain the basic features of data in the study through measure of central tendency, measure of variability and measure of dispersion. It forms a major component of quantitative data analysis. This analysis explained in measuring the distributional aspects of data to cluster around central value, symmetry of data and variability within the data. As presented in Table 28.2, the values for central tendency are found to be ranging between 8.7184 and 84.242 for the mean, 7.000-83.000 for median. The values for measuring the spread are found to be in the range of 1.149-12.248. The values for dispersion are found to be in the range of -1.023 to 0.897 for skewness and 0.102-1.942 for kurtosis. The ranges obtained during explained that the data is symmetrical, normally distributed, bell shaped, centered and unimodal.

\subsubsection{Reliability Analysis}

Reliability measures the degree to which the instrument can yield same results on repeated trials. In order to evaluate a survey instrument, an internal consistency check has been performed using Cronbach's alpha test. The employed indicators in the instrument has resulted in high reliability with the threshold level of Cronbach alpha greater than or equal to 0.60 on average. As mentioned in Table 28.3 the composite reliability shows outputs that range from 0.597 to 0.752 , which is nearly equivalent and larger than the threshold level 0.6. The Inter-item Correlation matrix represents a mean value of $0.039-0.165$, which signifies that all the items are positively correlated and measures a single unidimensional latent construct. The employed indicators for all the mentioned constructs i.e. Motivational factors, Perceived desirability, Entrepreneurial potential and Entrepreneurial intention are found to be reliable and hence justifying the adequacy of the sample.

Table 28.2 Descriptive analysis

\begin{tabular}{l|l}
\hline Measure & Value ranges \\
\hline Mean & 8.7184 to 84.242 \\
\hline Median & 7.000 to 83.000 \\
\hline Standard deviation & 1.149 to 12.248 \\
\hline Skewness & -1.023 to 0.897 \\
\hline Kurtosis & 0.102 to 1.942
\end{tabular}


Table 28.3 Reliability analysis

\begin{tabular}{l|l|l|l|l|l}
\hline Constructs & $\begin{array}{l}\text { No. of } \\
\text { items }\end{array}$ & $\begin{array}{l}\text { Item scale } \\
\text { mean }\end{array}$ & $\begin{array}{l}\text { Inter-item } \\
\text { covariance }\end{array}$ & $\begin{array}{l}\text { Inter-item } \\
\text { correlation }\end{array}$ & $\begin{array}{l}\text { Cronbach's } \\
\text { alpha }\end{array}$ \\
\hline $\begin{array}{l}\text { Motivational } \\
\text { factors }\end{array}$ & 17 & 3.274 & 0.181 & 0.122 & 0.703 \\
\hline Optimism & 6 & 2.767 & 0.114 & 0.178 & 0.597 \\
\hline $\begin{array}{l}\text { Cognitive } \\
\text { flexibility }\end{array}$ & 11 & 3.699 & 0.003 & 0.039 & 0.688 \\
\hline $\begin{array}{l}\text { Entrepreneurial } \\
\text { intensity }\end{array}$ & 4 & 3.08 & 0.118 & 0.271 & 0.752 \\
\hline $\begin{array}{l}\text { Action control } \\
\text { scale }\end{array}$ & 23 & 3.663 & 0.165 & 0.051 & 0.633 \\
\hline $\begin{array}{l}\text { Perceived } \\
\text { desirability }\end{array}$ & 3 & 4.324 & 0.104 & 0.159 & 0.712 \\
\hline $\begin{array}{l}\text { Entrepreneurial } \\
\text { intention }\end{array}$ & 2 & 4.184 & 0.55 & 0.131 & 0.694 \\
\hline
\end{tabular}

\subsubsection{Validity Test}

The Content Validity is defined as an extent to which a variable represents all facets of a given construct. An attempt has been made for content clarity using Delphi method by performing the check for wordings, statements for the instruments by experts in this field. Construct validity is defined as the degree to which a test measures what it claims to be measuring. It explains the nature of an underlying construct along with its relationship with other constructs in an instrument. In order to understand the association of variables, Pearson product correlation analysis has been conducted as presented in Table 28.4. There are two subsets of construct validity i.e. convergent and discriminant construct validity. Convergent construct validity tests the relationship between the construct and a similar measure while discriminant validity tests the

Table 28.4 Pearson-correlation matrix

\begin{tabular}{l|l|l|l|l|l|l|l}
\hline Constructs & Mov_total & PD_total & Optm_total & Int_total & EI_total & ACS_total & Int_total \\
\hline Mov_total & 1 & - & - & - & - & - & - \\
\hline PD_total & $0.448^{\mathrm{b}}$ & 1 & - & - & - & - & - \\
\hline Int_total & $0.418^{\mathrm{b}}$ & 0.017 & 1 & - & - & - & - \\
\hline CF_total & 0.079 & 0.127 & $0.207^{\mathrm{b}}$ & 1 & - & - & - \\
\hline EI_total & $0.708^{\mathrm{b}}$ & 0.143 & 0.144 & 0.155 & 1 & - & - \\
\hline ACS_total & $0.358^{\mathrm{b}}$ & $0.214^{\mathrm{b}}$ & $0.568^{\mathrm{b}}$ & $0.651^{\mathrm{b}}$ & $0.570^{\mathrm{b}}$ & 1 & \\
\hline Int_total & 0.021 & $0.368^{\mathrm{b}}$ & 0.076 & $0.220^{\mathrm{a}}$ & $0.216^{\mathrm{a}}$ & 0.090 & 1 \\
\hline
\end{tabular}

${ }^{\text {a }}$ Correlation is significant at the 0.05 level (2-tailed)

${ }^{\mathrm{b}}$ Correlation is significant at the 0.01 level (2-tailed) 
relationships between the construct and an unrelated measure. In order to have good construct validity one must have a strong relationship with convergent construct validity and no relationship for discriminant construct validity.

As observed in the Table 28.4, it has found that i.e. entrepreneurial intensity shows a convergent relationship with optimism i.e. 0.651 at significant level 0.01 and also shows similar relationship with Cognitive Flexibility i.e. 0.570 at significant level 0.01 which further explains the variables are correlated and measures the same construct i.e. Entrepreneurial Potential. The discriminant relationship has been observed too in case of perceived feasibility and intention, optimism, cognitive flexibility and perceived desirability which explains the fact that these variables are discriminant. Hence, it explains that the instrument used for the study is valid.

\subsubsection{Hypothesis Testing}

In order to understand the strength and direction of association between the variables, the Spearmen's correlation test has performed. The following hypothesis has been tested as presented in Table 28.5.

Table 28.5 Hypothesis statement

\begin{tabular}{l|l}
\hline S. No. & Hypothesis \\
\hline $\mathrm{H}_{1}$ & $\begin{array}{l}\text { There would be a positive relationship between motivation and perceived } \\
\text { desirability }\end{array}$ \\
\hline $\mathrm{H}_{2}$ & $\begin{array}{l}\text { There would be a positive relationship between perceived desirability and } \\
\text { entrepreneurial potential }\end{array}$ \\
\hline $\mathrm{H}_{3}$ & $\begin{array}{l}\text { There would be a positive relationship between entrepreneurial potential and } \\
\text { Entrepreneurial intention }\end{array}$ \\
\hline $\mathrm{H}_{4}$ & $\begin{array}{l}\text { There would be a positive relationship between motivation and entrepreneurial } \\
\text { potential }\end{array}$ \\
\hline $\mathrm{H}_{5}$ & $\begin{array}{l}\text { There would be a positive relationship between motivation and entrepreneurial } \\
\text { intention }\end{array}$ \\
\hline
\end{tabular}

Table 28.6 Spearmen's correlation test

\begin{tabular}{l|l|l|l|l}
\hline Constructs & Mov_total & EP_total & PF_total & Int_total \\
\hline Mov_total & 1 & - & - & - \\
\hline EP_total & $0.220^{\mathrm{a}}$ & 1 & - & - \\
\hline PF_total & $0.293^{\mathrm{b}}$ & $0.372^{\mathrm{b}}$ & 1 & - \\
\hline Int_total & $0.801^{\mathrm{a}}$ & $359^{\mathrm{b}}$ & 0.157 & 1 \\
\hline
\end{tabular}

${ }^{\mathrm{a}}$ Correlation is significant at the 0.05 level (2-tailed)

${ }^{\mathrm{b}}$ Correlation is significant at the 0.01 level (2-tailed) 
The results presented in Table 28.6 shows that there is a significant positive correlation between Motivation and Perceived desirability $(\mathrm{rs}=0.29, \mathrm{~N}=397, \mathrm{p}=0.003$, two-tailed). It is observed that Perceived desirability and Entrepreneurial potential exhibited positive correlation ( $\mathrm{rs}=0.37, \mathrm{~N}=397, \mathrm{p}<0.001$, two-tailed). Also, the positive correlation has found between various constructs i.e., Entrepreneurial potential and Entrepreneurial intention ( $\mathrm{rs}=0.35, \mathrm{~N}=397, \mathrm{p}=0.001$, two-tailed), Motivation and Entrepreneurial potential $(\mathrm{rs}=0.22, \mathrm{~N}=397, \mathrm{p}=0.026$, two-tailed) and Motivation and Entrepreneurial intention ( $\mathrm{rs}=0.80, \mathrm{~N}=397, \mathrm{p}<0.001$, twotailed) at 0.05 and 0.01 significant level respectively. The empirical analysis implies that all the hypotheses are accepted.

Further to this, the result suggests that the increase in motivation among women entrepreneurs lead to high-perceived desirability, which in turn will lead to more entrepreneurial potential and hence resulting in more venture creation.

\subsection{Findings, Conclusion and Recommendation}

This research was mainly conceptualized to understand the constructs of Entrepreneurial intention. The study addressed the role of motivation in influencing perceived desirability, entrepreneurial potential towards the entrepreneurial intention. In addition, it was observed that Push factors enable the perceived feasibility more than the pull factors. Through hypothesis testing the above relationship among constructs were validated and established. It also confirms that for any behavior to happen among women entrepreneurs, the antecedents like motivational factors, perceived feasibility and entrepreneurial potential plays a major role. These findings are in line with the previous literature on how motivational factors lead to entrepreneurial intentions through entrepreneurial potential.

As stated from the Government perspective, this model will help in designing Training and Development programs for promoting women entrepreneurship in India. It will also help the policy makers, educational institutions and incubation centers to look into the lines of promoting women entrepreneurship in India with a systematic approach.

\section{References}

Ahl H (2006) Why research on women entrepreneurship needs new direction. Entrep Theory Pract J 30(2):595-621

Anwar MU, Rashid AG (2012) Female entrepreneurs-a review of the literature and proposed conceptual framework. In: Proceedings of 2 nd international conference on business management, pp $1-30$

Ascher J (2012) Female entrepreneurship—an appropriate response to gender discrimination. JEMI 8(1):97-114. https://doi.org/10.7341/2012847 
Bird B, Brush C (2002) A gendered perspective on organizational creation. Entrep Theory Pract 26(3):41-65. https://doi.org/10.1177/104225870202600303

BNP Paribas (2015) Global entrepreneurial report: tracing the wealth creating paths of entrepreneurs and angles, pp 1-52

Carter S, Cannon T (1988) Female entrepreneurs: a study of female business owners, their motivations, experiences and strategies for success. Academic Press, London

Cavada M, Bobek V, Maček A (2017) Motivation factors for female entrepreneurship in Mexico. Entrep Bus Econ Rev 5(3):133-148. https://doi.org/10.15678/EBER.2017.050307

Chandrasekar et al (2008) Women entrepreneurship in India Fillip to Christian and Islamic, women state of Kerala, India. Ahfad J 25(1):150-171

Dwivedi TN, Mishra T (2013) Women empowerment through women entrepreneurship (A Study Of Faizabad Zone of Uttar-Pradesh). Voice Res J 2(5):50-55

Government of the People's Republic of Bangladesh (2010) National Industrial Policy, pp 3-6

Hisrich RD, Candida G (1984) The Woman entrepreneur: management skills and business problems. J Small Bus Manag 22(1):30-37

IFC Issue Brief/Small and Medium Enterprises (2010), pp 1-2

Irengun O, Arikboga S (2015) The effect of personality traits on social entrepreneurship intentions: a field research. Proc Soc Behav Sci 195(3). https://doi.org/10.1016/j.sbspro.2015.06.172

Kelley DJ et al (2012) Global Entrepreneurship Research Association (GERA). Global entrepreneurship monitor 2012 Women's report, pp 1-56

Krueger N (2015) Thematic paper on entrepreneurial education in practice: part 1-the entrepreneurial mindset. http://www.oecd.org/cfe/leed/Entrepreneurial-Education-Practice-pt1. pdf

Krueger NF, Brazeal DV (1992) Entrepreneurial potential and potential entrepreneurs. Entrep Theory Pract 18(3):91-104. https://doi.org/10.1177/104225879401800307

Krueger NF, Carsrud A (1995) Entrepreneurial intentions: applying the theory of planned behaviour. Entrep Reg Dev 5(4):315-330. https://doi.org/10.1080/08985629300000020

Kurbah S (2013) Role of women entrepreneurs in the economic development of Meghalaya: a North Eastern State, India. Int Assoc Sci Innov Res 3(1):175-183

Lent RW, Brown SDY, Hackett G (1994) Toward a unifying social cognitive theory of career and academic interest, choice, and performance. J Vocat Behav 45(1):79-122

Lent RW, Brown SD, Hackett G (2000) Contextual supports and barriers to career choice: a social cognitive analysis. J Couns Psychol 47(2):36-49. https://doi.org/10.1037/0022-0167.47.1.36

Lituchy TR, Reavley MA (2015) Women entrepreneurs: a comparison of international small business owners in Poland and the Czech Republic. J Int Entrep 2(1):61-87. https://doi.org/10.1023/ B:JIEN.0000026906.28190.df

Mallya LS (2012) A thesis on successful entrepreneurs of Indian origin: case study

Mani C (2011) Forces behind entrepreneurship of women — an economic study. Int J Bio-resour Stress Manag 2(1):355-358

Marichamy K (2013) Rural Women entrepreneurship. In: Madurai, Tamil Nadu. Tactful Manag Res J 2(13): 1-8

Masood RZ (2011) Emergence of women-owned businesses in India—an insight. J Art Sci Commerc 2(1):233-243

Mustafa Z (2013) Prospects and challenges of women entrepreneurship: a study of the women entrepreneurs of Jammu and Kashmir. Nat Mon Refereed J Res Commerc Manag 4(1):81-91

Nagalakshmi T (2015) Women entrepreneurship: government and institutional support in Andhra Pradesh-a study. J Econ Manag 4(1):205-229

Nga JKH, Shamuganathan G (2010) The influence of personality traits and demographic factors on social entrepreneurship start up intentions. J Bus Ethics 95(2):259-282. https://doi.org/10.1007/ s10551-009-0358-8

Rummana R (2014) Theorizing women entrepreneurship—in pursuit of a definition in the light of literature-the case of Bangladesh. Int J Adv Technol Eng Res 5(2):246-253 
Shah AF, Mustafa Z (2014) Prospects of women entrepreneurship: a study of the women entrepreneurs of Kashmir Valley. Pinnacle Res J 4(2):103-116

Sharma Y (2013) Women entrepreneur in India. IOSR J Bus Manag 15(1):9-14

Shiralashetti AS (2014) Problems of women entrepreneurs in district of North Karnataka-a diagnostic study. Int J Multidiscip Acad Res 2(1):1-13

Singh A, Raina M (2013) Women entrepreneurs in micro, small and medium enterprises. Int J Manag Soc Sci Res 2(8):1-8

Tarakeswara SR, Tulasi GR (2013) Women entrepreneurship in India (A Case Study) In Andhra Pradesh). J Commerc 3(1):132-140

Terjesen SA, Lloyd A (2015) The 2015 female entrepreneurship index (June 18, 2015). Kelley School of Business Research Paper No. 15-51. https://doi.org/10.2139/ssrn.2625254

Thomas S, Lavanya VL (2012) A study on the growth and performance of selected women entrepreneurs in Coimbatore District, Tamil Nadu. IUP J Entrep Dev 9(2):80-88

Vinze MD (1987) Women entrepreneurs in India. Mittal Publications, New Delhi. Dubhashi M (2011) Small-scale women entrepreneurship in readymade garment industry—an overview. Mittal Publications, New Delhi

Open Access This chapter is licensed under the terms of the Creative Commons Attribution 4.0 International License (http://creativecommons.org/licenses/by/4.0/), which permits use, sharing, adaptation, distribution and reproduction in any medium or format, as long as you give appropriate credit to the original author(s) and the source, provide a link to the Creative Commons license and indicate if changes were made.

The images or other third party material in this chapter are included in the chapter's Creative Commons license, unless indicated otherwise in a credit line to the material. If material is not included in the chapter's Creative Commons license and your intended use is not permitted by statutory regulation or exceeds the permitted use, you will need to obtain permission directly from the copyright holder.

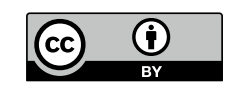

